\title{
Epidemiological Aspects of Rotavirus Infections in Minas Gerais, Brazil
}

\author{
Maria Luzia da Rosa e Silva, Felipe Gomes Naveca \\ and Iná Pires de Carvalho
}

\author{
Virology Department, Professor Paulo de Góes Istitute \\ of Microbiology, Federal University of Rio de Janeiro, \\ RJ, Brazil; Department of Microbiology, Federal \\ University of Juiz de Fora, MG, Brazil
}

\begin{abstract}
In order to develop good polices regarding public health measures and vaccine use to prevent rotavirus induced gastroenteritis, the epidemiology of the illness in various regions of Brazil is necessary. Accordingly, this study was to detect the frequency and types of rotavirus in one city in a tropical part of Brazil. This is an epidemiological survey of pediatric gastroenteritis caused by rotavirus conducted in Juiz de Fora, Minas Gerais State, Brazil. We analyzed 656 in-patient (190) and out-patient (466) stool samples from children ages 0 to 5 years during 1998. Rotavirus detection was performed using polyacrylamide gel electrophoresis (PAGE). Rotavirus was isolated from 62/190 stool samples (32.6\%) from hospitalized children and 16/466 (3.4\%) from outpatients. The overall rotavirus frequency in this population was $11.9 \%$. The highest rotavirus detection was found in hospitalized children ages 6 to 24 months. Rotaviruses were detected from March to September, with a peak incidence in June (33.3\%), the coldest and driest month in the region. Electrophoretic analysis identified 10 different profiles, all long and compatible with group A rotavirus, termed $L_{A}$ through $L J$. The $L_{B}$ and $L_{D}$ profiles circulated throughout most of the study period. However, in June, when the highest detection rate occurred, the vast majority $(\mathbf{9 2 . 5 \%})$ of the positive samples displayed the $L_{B}$ profile, thus suggesting an outbreak caused by this rotavirus profile. Rotavirus induced gastroenteritis is common in one tropical region of Brazil, it is an important cause of diarrhea in hospitalized children ages 6 to 24 months, it is most common during dry, cold months of the year, and it may occur in electrophoretype restricted epidemics. Such analyses throughout Brazil will assist in developing sound guidelines regarding its prevention.
\end{abstract}

Key Words: Rotavirus, gastroenteritis, epidemiological survey, seasonality, electrophoretic patterns.

Gastroenteritis is one of the main causes of infantile morbidity worldwide [1,2]. Rotaviruses are considered the main etiologic agents of non-bacterial acute diarrhea

Received on 13 April 2001; revised 17 May 2001.

Address for correspondence: Dr. Maria Luzia da Rosa e Silva Departamento de Virologia, Instituto de Microbiologia Professor Paulo de Góes, Universidade Federal de Rio de Janeiro. Cidade Universitária, CCS - Bl I, Ilha do Fundão. Caixa Postal 68040, Rio de Janeiro, RJ, Zip code: 21941-590, Brazil. Phone: (21)-260-9311. Fax: 021-560-8344. E-mail: imviica@microbio.ufrj.br. This work was supported by CAPES and SR2-UFRJ, Brazil.

The Brazilian Journal of Infectious Diseases 2001;5(4):215-222 (C) 2001 by The Brazilian Journal of Infectious Diseases and Contexto Publishing. All rights reserved.

1413-8670 among children worldwide and, in developing countries, the infection takes on particularly serious characteristics leading to a high infant mortality rate [3].

Rotaviruses belong to the Reoviridae family, whose genome consists of 11 double-strand RNA segments. By polyacrylamide gel electrophoresis (PAGE), these segments can be separated into welldefined bands, forming characteristic migration profiles termed electrophoretypes. Electrophoretic analysis of rotavirus samples is a useful epidemiological tool, that has shown us the coexistence of different strains during diarrheal disease, the appearence of new strains and disapperence of old strains from a community, and the shifts in the prevalence of strains. Group A 
rotaviruses have the greatest epidemiological importance since they are involved in the majority of rotavirus infections worldwide.

Genomic alterations in rotavirus appear to occur more frequently in developing and tropical countries where climatic conditions favor continuous viral transmission, facilitating the occurrence of genetic processes causing such alterations [4]. In Brazil, rotaviruses have been identified as the main cause of diarrheal disease, having been detected in $13 \%$ to $40 \%$ of patients [5].

The high morbidity rates caused by rotaviruses in both developed and developing countries have led to increased research efforts to obtain an effective vaccine against the more severe cases. Current candidate vaccines are comprised of the most common types of rotavirus found in the world [6]. However, epidemiological studies in Brazil have detected uncommon types of circulating rotavirus strains different from those used in the vaccines currently under study $[7,8]$.

Based on this knowledge, our objective was to study epidemiological aspects of diarrheal infection in the city of Juiz de Fora, Minas Gerais, Brazil, where no previous data on rotavirus gastroenteritis had been reported.

\section{Materials and Methods}

The research was carried out in Juiz de Fora (pop. 424,479), Minas Gerais State, Brazil. The climate is referred to as high tropical character. Data on temperature and rainfall during the study period were provided by the Meteorology Laboratory of the Federal University in Juiz de Fora.

We analyzed 656 stool samples from January to December, 1998, from children ages 0 to 5 years. Of these fecal specimens, 190 were obtained from hospitalized children that acquired illness in the community and the specimens were liquid when feces were taken. Of the 466 fecal specimens obtained from non hospitalized children, $14 \%$ were liquid when feces were taken. Fecal samples were sent to our laboratory and stored at $-20^{\circ} \mathrm{C}$ until being processed by viral RNA extraction.
After extraction [9], viral RNA was submitted to electrophoresis using the technique described by Laemmli [10], fixed in slab gels of $7.5 \%$ acrylamide and $0.30 \%$ bis-acrylamide, and run for $130 \mathrm{~min}$ at $120 \mathrm{~V}$. Simian rotavirus strain SA-11 was used in all runs as a standard. Gels were stained with silver nitrate by methods described by Herring, et al. [11]. Gels were fixed for 30 min in $10 \%$ ethanol, $5 \%$ acetic acid, followed by 30 min staining in $0.2 \%$ silver nitrate. After rising in distilled water, the gel was developed in a $10 \%$ sodium hydroxide with $0.75 \%$ formaldehyde until bands were well resolved.

\section{Results}

Analysis of the 656 fecal specimens revealed 78 positive samples, a rotavirus incidence of $11.9 \%$. Of the 78 positive rotavirus samples, $79.5 \%(62 / 78)$ were from hospitalized children and 20,5\% (16/78) from non-hospitalized children (Table1). The frequency of isolation was 62/190 (32.6\%) from hospitalized children and 16/466 (3.4\%) from non-hospitalized children.

The monthly distribution and positive sample rates during the study period are shown in Figure 1.The distribution of rotavirus infection of the 53 patients that were classified into 5 age groups is shown on Table 2. To obtain a correlation between rotavirus incidence and climatic factors, we compared the number of positive samples month by month with the mean monthly temperatures and rainfall (Figure 2). We observed that, from May to August, the rotavirus detection rates were $18 \%, 35 \%, 24.5 \%$, and $12.9 \%$, respectively, with June and July showing the highest positive rates coinciding with the coldest and driest season of the year. In contrast, we did not record any cases of rotavirus in the hottest and rainiest months.

By electrophoretic analysis, we distinguished 10 different RNA profiles, all compatible with group A rotavirus and classified in order of appearance from LA to LJ. Monthly distribution of the profiles is shown on Table 3 and the scheme for different electrophoretypes in Figure 3. 
Table 1. Detection of rotavirus infections in hospitalized and non-hospitalized children from January to December 1998

\begin{tabular}{|c|c|c|c|c|}
\hline \multirow[t]{2}{*}{ Patients } & \multicolumn{2}{|c|}{ Positive } & \multicolumn{2}{|c|}{ Negative } \\
\hline & $\mathbf{N}^{\circ}$ & $\%$ & $\mathbf{N}^{0}$ & $\%$ \\
\hline $\begin{array}{l}\text { Hospitalized }^{\mathrm{a}} \\
(\mathrm{n}=190)\end{array}$ & 62 & 32.6 & 128 & 67.4 \\
\hline $\begin{array}{l}\text { Non-hospitalized }^{b} \\
(\mathrm{n}=466)\end{array}$ & 16 & 3.4 & 450 & 96.6 \\
\hline $\begin{array}{l}\text { Total } \\
(n=656)\end{array}$ & 78 & 11.9 & 578 & 88.1 \\
\hline
\end{tabular}

Table 2. Distribution by age group of 53 rotavirus positive cases occurred in Juiz de Fora city, 1998

\begin{tabular}{lccccc}
\hline $\begin{array}{l}\text { Age group } \\
\text { (in months) }\end{array}$ & $0-6$ & $6-12$ & $13-24$ & $25-36$ & $37-60$ \\
$\begin{array}{l}\text { Rotavirus positive cases } \\
(\%)\end{array}$ & 9 & 17 & 18 & 5 & 4 \\
\hline
\end{tabular}

Table 3. Monthly distribution of different eletropherotypes detected in positives rotavirus stools during 1998

\begin{tabular}{|c|c|c|c|c|c|c|c|c|c|c|c|c|c|}
\hline e-types & Jan & Feb & Mar & Apr & May & Jun & Jul & Aug & Sep & Oct & Nov & Dec & Total \\
\hline $\mathrm{L}_{\mathrm{A}}$ & - & - & 1 & 2 & 1 & - & - & - & - & - & - & - & 4 \\
\hline $\mathrm{L}_{\mathrm{B}}$ & - & - & 1 & 1 & 7 & 25 & 2 & 2 & 1 & - & - & - & 39 \\
\hline $\mathrm{L}_{\mathrm{C}}^{\mathrm{D}}$ & - & - & 1 & - & 2 & - & - & - & - & - & - & - & 3 \\
\hline $\mathrm{L}_{\mathrm{D}}$ & - & - & - & - & 4 & 1 & 7 & 6 & - & - & - & - & 18 \\
\hline $\mathrm{L}_{\mathrm{E}}$ & - & - & - & - & - & 1 & 2 & - & - & - & - & - & 3 \\
\hline $\mathrm{L}_{\mathrm{F}}$ & - & - & - & - & - & - & 1 & - & - & - & - & - & 1 \\
\hline $\mathrm{L}_{\mathrm{G}}$ & - & - & - & - & - & - & 2 & - & - & - & - & - & 2 \\
\hline $\mathrm{L}_{\mathrm{H}}$ & - & - & - & - & - & - & 5 & - & - & - & - & - & 5 \\
\hline $\mathrm{L}_{\mathrm{I}}$ & - & - & - & - & - & - & - & 2 & - & - & - & - & 2 \\
\hline $\mathrm{L}_{\mathrm{J}}$ & - & - & - & - & - & - & - & - & 1 & - & - & - & 1 \\
\hline
\end{tabular}


Figure 1. Monthly distribution of total and positive rotavirus stools from January to December, 1998

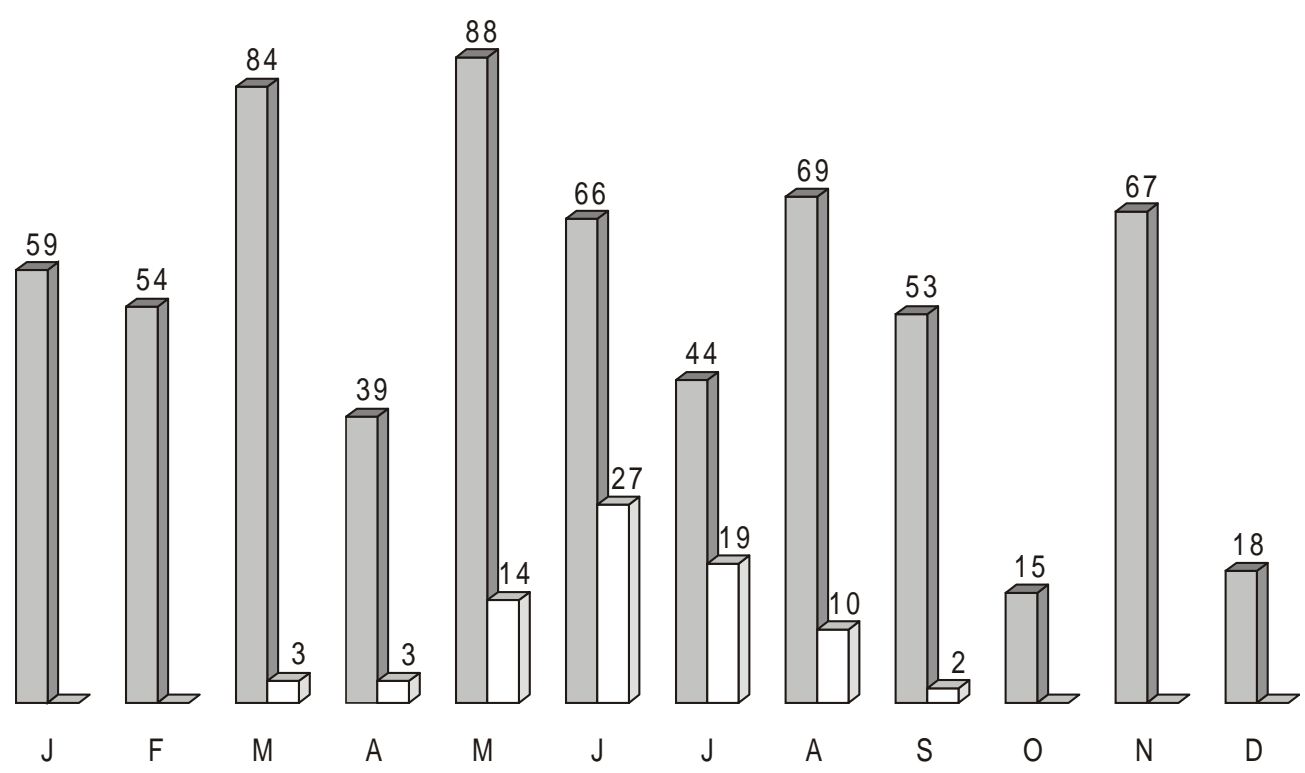

Figure 2. Correlation between the incidence of positive samples and the monthly mean of temperature and rainfall, during 1998

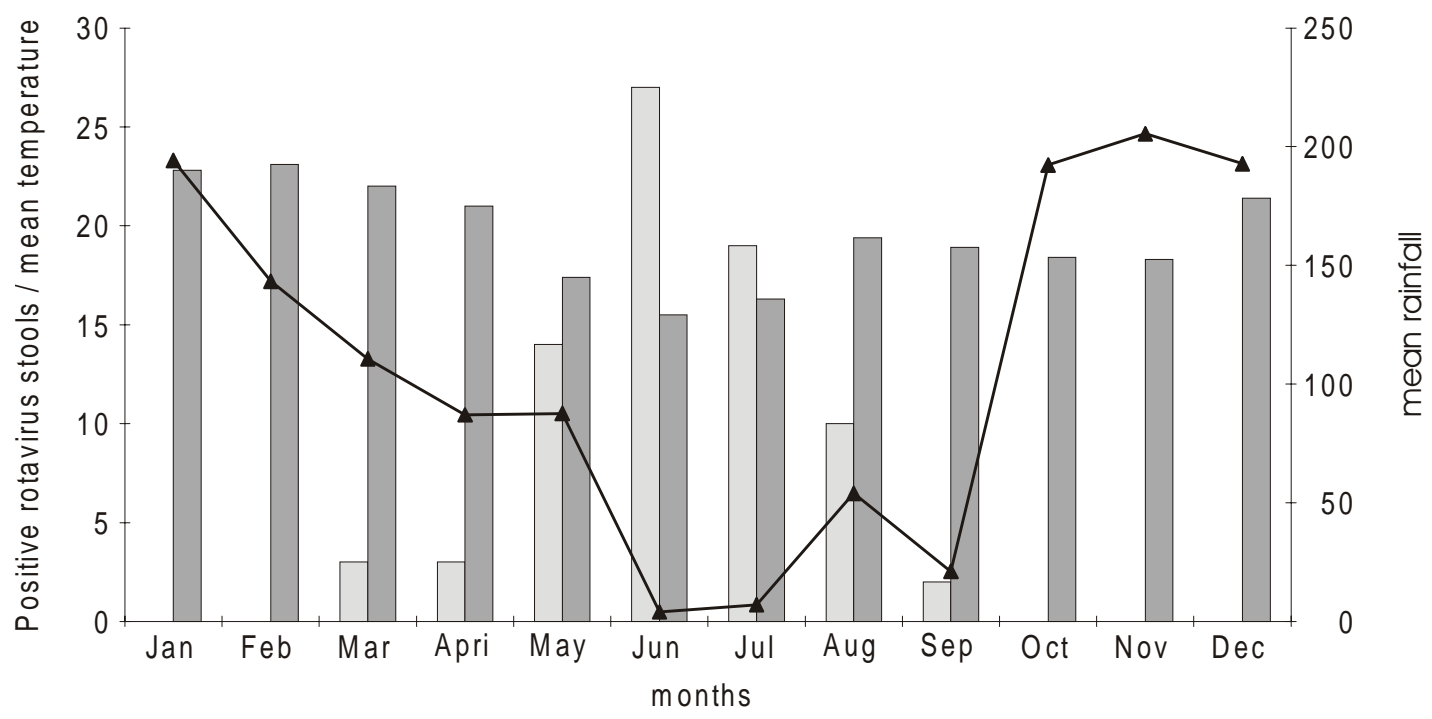


Figure 3. Different rotavirus electropherotypes detected in this study, during 1998

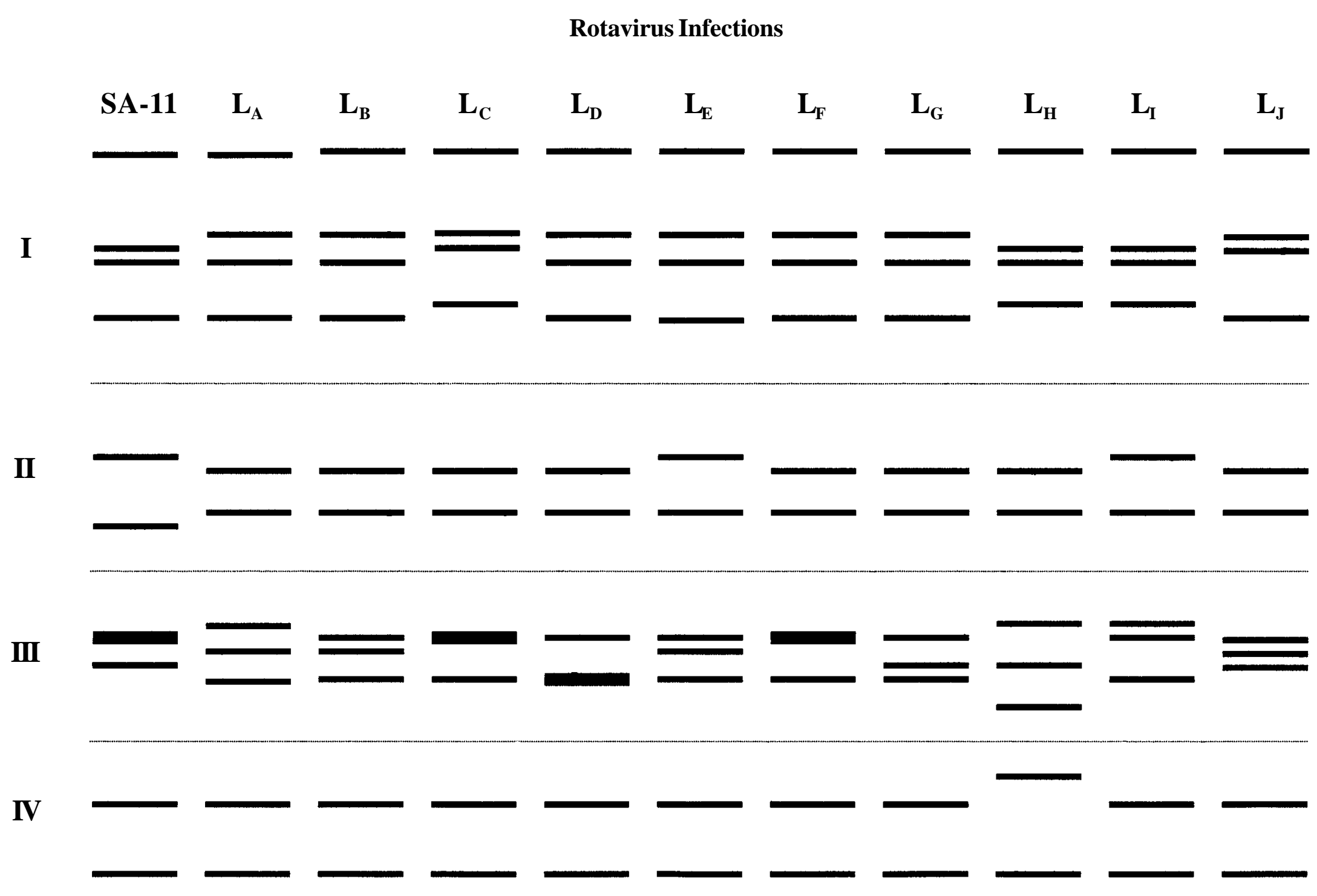




\section{Discussion}

In Brazil, the presence of rotavirus has been demonstrated in several states by detecting the virus in feces [12-15], sewage, and rivers [16], as well as by serological surveys $[17,18]$, thus confirming the intense circulation of this enteropathogen in the country.

Data analysis showed a positive rotavirus rate of 11.9\% (78/656). However, in hospitalized children, the positive rate of $79.5 \%(62 / 78)$ was 3 times that of the out-patient group. This reinforces the association between more severe cases of gastroenteritis and rotavirus infection, as demonstrated in early studies based on high prevalence among hospitalized patients, thus showing the significant involvement of this virus with more severe cases of gastroenteritis [5, 14, 19-21].

We observed that $83 \%$ of cases of acute gastroenteritis, in which we detected rotavirus, occurred in children under 2 years of age; a finding compatible with other studies both in Brazil and abroad [3, 2224] emphasizing that a rotavirus vaccine should be administered in the first months of life in order to prevent the most severe cases of gastroenteritis.

One of the most striking epidemiological characteristics of rotavirus infection is its seasonality, so we were interested in observing the frequency of detection month by month. The positive samples were detected in the driest months of the year in Juiz de Fora, mainly among hospitalized children. We observed peak rotavirus incidence in June (35\%) and July (24.3\%), thus displaying seasonal variation in the circulation of these viruses.

Various factors, including climate and host behavior, can be involved in infection by these viral agents as demonstrated in several studies that showed a variety of seasonal patterns [25]. Previous data have shown that rotavirus incidence is higher in the winter in regions with temperate climates [3]. Otherwise, in developing countries with tropical climates such as Brazil, variations in frequency of rotavirus infection have been observed, probably due to climatic differences. Thus, the virus can be detected throughout the year in such regions without a well-defined seasonal distribution, or there may be a marked incidence in the coldest and driest months [5, 15].

Moe and Shirley [26] observed that low temperatures had a direct influence on rotavirus survival in nature. These studies were performed in countries with temperate climates, but our data also point to the same correlation thus reinforcing the influence of temperature on rotavirus detection.

In Juiz de Fora, peak rotavirus detection also coincided with the driest month of the year in agreement with data from Konno, and colleagues [27], in Japan. This epidemiological pattern was observed in southeastern, northeastern, and central states of Brazil [28-30] and abroad [31-34]. Therefore, even where there are overall climatic differences, rotavirus detection appears to be correlated with the driest and coldest periods of the year.

Throughout the study period there was cocirculation of different profiles with LA and LB predominating, as reported before [35]. While LD circulated from May to August, LB was present throughout the entire period in which rotaviruses were detected (March to September). This profile comprised $50 \%$ (39/78) of all positive samples and nearly all ( $92.5 \%$ ) of the positive samples detected in June (25/ 27). The high LB incidence may be indicative of an outbreak in the city caused by this rotavirus profile.

\section{Acknowledgements}

We thank Cyríaco Brandão, Cortes Villela, Biolab, Milton Ladeira Clinical Laboratories and Nossa Senhora das Graças, Furtado de Menezes Health Units of Juiz de Fora city for supplying the stool samples used in this study.

\section{References}

1. Bern C., Martines, J., De Zoysa I., Glass R.I. The magnitude of the global problem of diarrheal disease: a 10 year update. Bull WHO 1992;70:705-14.

2. Murray C.G., Lopes A.D. Global mortality disability and the contribution of risk factors: global burden of disease study. Lancet 1997;349:1436-42. 
3. Kapikian A.Z., Chanock R.M. Rotaviruses. In Fields Virology , 3rd ed., Lippincott-Raven, Philadelphia, 1996; 1657-708.

4. Gouvea V., Brantly M. Is rotavirus a population of reassortants? Trends Microbiol 1995;3:159-62.

5. Pereira H.G., Linhares A,C., Candeias J.A.N., Glass, RI. National laboratory surveillance of viral agents of gastroenteritis in Brazil. Bull Pan Am Health Organ 1993; $27: 224-33$.

6. Hoshino Y., Kapikian A.Z. Classification of rotavirus VP4 and VP7 serotypes. Arch Virol 1996;12(Suppl.1):99-100.

7. Das B.K., Gentsch J.R., Cicirello H.G., et al. Characterization of rotavirus strains from newborns in New Delhi, India. J Clin Microbiol 1994;32:1820-2.

8. Gouvea V., de Castro L.,Timenetsky M.C., et al. Rotavirus serotype G5 associated with diarrhea in Brazilian children. J Clin Microbiol 1994;32:1408-140.

9. Santos N., Gouvea V. Improved method for purification of RNA from fecal specimens for rotavirus detection. J Virol Meth 1994;46:11-21.

10. Laemmli U.K. Cleavage of structural proteins during the assembly of the head of bacteriophage T4. Nature (London) 1970;227:680-5.

11. Herring A.J., Inglis N.F., Ojeh C.K., et al. Rapid diagnosis of rotavirus infection by direct detection of viral nucleic acid in silver-stained polyacrylamide gels. J Clin Microbiol 1982;16:473-537.

12. Pereira H.G., Azeredo R.S., Leite J.P.G., et al. Electrophoretic study of the genome of human rotaviruses from Rio de Janeiro, São Paulo and Pará, Brazil. J Hygiene (London) 1983;90:117-25.

13. Coiro J.R.R., Neto A.J.A, Heuser M.C.F., et al. Acute enteritis associated with rotavirus presence in Brasilian children: evaluations on prevalence, therapy and age group. J Diarrhoeal Dis Res 1985;3:78-83.

14. Timenetsky M.C.S.T., Kisiellius J.J., Grisi S.J.F.E., et al. Rotavírus, adenovírus, astrovírus, calicivírus e "small round virus particles" em fezes de crianças, com e sem diarréia aguda, no período de 1987 a 1988, na grande São Paulo. Rev Inst Med Trop S Paulo 1993;35:275-80.

15. Gusmão R.H.P., Mascarenhas J.A P., Gabbay I.B., et al. Rotavirus group, $\mathrm{G}$ serotypes and electrophoretypes in cases of nosocomial infantile diarrhea in Belém, Brazil. J Trop Pediat 1999;45:81-6.

16. Mehnert D.U., Stewien K.E. Detection and distribution of rotavirus in raw sewage and creeks in São Paulo, Brazil. Appl Envirl Microbiol 1993;59(1):140-3.

17. Ishak R., Linhares A.C., Gabbay Y., et al. Soroepidemiologia de rotavírus em uma população infantil, Goiânia, Goiás, Brasil. Rev Inst Med Trop S Paulo, 1984;26:280-4.

18. Cox M.J., Azevedo R.S., Nokes D.J., et al. Seroepidemiology of group A rotavirus in suburban São Paulo, Brazil. Epidemiol Infect 1998; 120:327-34.
19. Linhares A.C., Gabbay Y.B., Mascarenhas J.A.P., et al. Epidemiology of rotavirus gastroenteritis in the Amazon region and the need for a specific vaccine. J Braz Assoc Advanced Science 1992;44:152-7.

20. Molbak K., Wested N.H., Hojlyng N., et al. The etiology of early childhood diarrhea: a community study from Guinea-Bissau. J Infect Dis 1994;169:581-7.

21. Cama R.I., Parashar U.D., Taylor D.N., et al. Enterophatogens and other factors associated with severe diseases in children with acute watery diarrhea in Lima, Peru. J Infect Dis 1999;179:1139-44.

22. Linhares A.C. Rotavirus Infections in Brazil: epidemiology, immunity and potential vaccination. Braz J Infect Dis 1997; 1:284-93.

23. Barnes G.L., Uren E., Stevens K.B., Bishop R.F. Etiology of acute gastroenteritis in hospitalized children in Melbourne, Australia, from April, 1980, to March, 1993. J Clin Microbiol 1998;36(1):133-8.

24. Chan P.K.S., Tam J.S., Nelson E.A.S., et al.. Rotavirus infection in Hong Kong: epidemiology and estimates of disease burden. Epidemiol Infect 1998; 120:321-5.

25. Cook S.M., Glass R.I., Le Baron C.W., Ho M. Global seasonality of rotavirus infections. Bull WHO 1990;68:171-7.

26. Moe K., Shirley J.A. The effects of relative humidity and temperature on the survival of human rotavirus in faeces. Arch Virol 1982;72:179-86.

27. Konno T., Suzuki H., Katsushima N., et al. Influence of temperature and relative humidity on human rotavirus infection in Japan. J Infect Dis 1983; 147:125-8.

28. Guerrant R.L., Dirchoff L.V., Shields D.S., et al.. Prospective study of diarrhoeal illness in northeastern Brazil: patterns of disease, nutrition infancy, etiologies and risk factors. J Infect Dis 1983; 148:986-97.

29. Teixeira J.M.S., Figueiredo R.B., Santos H.M.P., et al. Aspectos epidemiológicos das infecções por rotavírus no Distrito Federal, Brazil. Rev Soc Bras Med Trop 1991;24:223-30.

30. Stewien K.E., Mehnert D.U., Hársi C.M., et al. Serotypes and electropherotypes of human rotavirus detected in the city of São Luís (MA), Brazil. Braz J Med Biol Res 1994;27:1355-61.

31. Maiya P.P., Pereira S.M., Mathan M., et al. Etiology of acute gastroenteritis in infancy and early childhood in southern India. Arch Dis Child 1977;52:482-5.

32 . Hiebler J.P., Sharon S., Nelson J.D., et al. Comparison of human rotavirus disease in tropical and temperate settings. Am J Dis Child (Chicago) 1978;132:853-8.

33. Black R.E., Merson M.H., Brown K.H., et al. Epidemiologic studies of acute gastroenteritis in Bangladesh. Presented at the $13^{\text {th }}$ Conference on Viral Diseases, U.S.Japan Cooperative Medical Science Program, Atlanta. 1979. 
34. Cunliffe N.A., Kilgore P.E., Breese J.S., et al. Epidemiology of rotavirus diarrhoea in Africa: a review to assess the need for rotavirus immunization. Bull WHO 1998; 76(5):525-37.
35. George-Courbot M.C., Monjes J., Beraud-Cassel A.M., et al.. Prospective longitudinal study of rotavirus infections in children from birth to two years of age in Central Africa. Annales de L'Instute Pasteur 1988; 139:421-8. 